13 Burch JW, Stanford N, Majerus PW. Inhibition of platelet prostaglandin synthetase by oral aspirin. 7 Clin Invest 1978;61:314-9.

14 Villa $S$, Livio $M$, de Gaetano $G$. The inhibitory effect of aspirin on platelet and vascular prostaglandins in rats cannot be completely dissociated. Br $\mathcal{F}$ Haematol $1979 ; 42: 425-31$.

15 Jaffe EA, Weksler BB. Recovery of endothelial cell prostacyclin production after inhibition by low doses of aspirin. $\mathcal{F}$ Clin Invest $1979 ; 63: 532-5$.

${ }^{16}$ Hanley SP, Bevan J, Cockbill SR, Heptinstall S. Differential inhibition by low dose aspirin of human venous prostacyclin synthesis and platelet thromboxane synthesis. Lancet 1981 ; : $: 969-71$.

17 Heptinstall S, Bevan J, Cockbill SR, Hanley SP, Parry MJ. Effects of a selective inhibitor of thromboxane synthetase on human blood platelet $W$ behaviour. Thromb Res 1980;20:219-30.

18 Preston FE, Whipps S, Jackson CA, French AJ, Wyld PJ, Stoddard CJ. Inhibition of prostacyclin and platelet thromboxane $A_{2}$ after low-dose aspirin. $N$ Engl f Med 1981 ;304:76-9.

19 Hoogendijk EMG, Ten Cate JW. Aspirin and platelets. Lancet 1980;i:93-4.

${ }^{20}$ Buchanan MR, Dejana E, Cazenave JP, Richardson M, Mustard JF, Hirsh J. Differences in inhibition of $\mathrm{PGI}_{2}$ production by aspirin in rabbit artery and vein segments. Thromb Res 1980;20:447-60.

(Accepted 20 fuly 1982)

\title{
Diagnostic value of 9 am plasma adrenocorticotrophic hormone concentrations in Cushing's disease
}

\author{
P M HORROCKS, D R LONDON
}

\begin{abstract}
Morning plasma adrenocorticotrophic hormone (ACTH) concentrations were measured in 58 normal subjects and seven patients with pituitary-dependent Cushing's syndrome (Cushing's disease). Particular note was taken of the time of venepuncture. The range of values for the normal subjects irrespective of timing was 9-77 $\mathrm{ng} / \mathrm{l}$. The range between 90 am and 930 am was 9-24 $\mathrm{ng} / \mathrm{l}$. In the patients with Cushing's disease the ACTH concentrations were in the range 39-109 $\mathrm{ng} / \mathrm{l}$.

To distinguish patients with Cushing's disease from normal subjects it is therefore important to define accurately the 9 am normal range, since these results show no overlap.
\end{abstract}

\section{Introduction}

The introduction of the radioimmunoassay of adrenocorticotrophic hormone (ACTH) has allowed circulating concentrations of plasma ACTH to be measured easily both in normal subjects and in patients with Cushing's disease. ${ }^{1-4}$ The belief that there is an overlap between the range of morning ACTH concentrations found in patients with Cushing's disease and that found in normal subjects has led to some confusion about the diagnosis of Cushing's disease, particularly for those who are not endocrinologists. We feel that the diagnostic difficulties due to this apparent overlap have arisen because of a failure to define accurately the timing of the normal range in normal subjects. We also believe that the traditional " 9 am" measurement of ACTH does distinguish patients with Cushing's disease from normal subjects if properly timed.

\section{Patients and methods}

A total of 58 normal control subjects were studied. The group comprised laboratory staff not receiving hospital treatment and inpatients who had no endocrine disorder and were not under stress: these patients were either women admitted for laparoscopic sterilisation or patients of either sex admitted to the ear, nose, and throat ward for aural toilet. None of the control group were taking any medication.

Queen Elizabeth Hospital, Birmingham B15 2TH

P M HORROCKS, MB, MRCP, lecturer, university department of medicine D R LONDON, DM, FRCP, consultant physician
A $20-\mathrm{ml}$ sample of heparinised blood was taken from each subject oj between 60 am and $930 \mathrm{am}$, the exact time of venepuncture being $\mathcal{W}_{W}$ noted. Seven patients with pituitary-dependent Cushing's disease were studied. The table outlines the criteria used to diagnose pituitary- $\vec{\omega}$ induced Cushing's disease. As part of their inpatient assessment blood $O$ was taken between 90 am and $930 \mathrm{am}$.

All samples were immediately cooled, spun at $4^{\circ} \mathrm{C}$, and the separated

Clinical details of seven patients with Cushing's disease

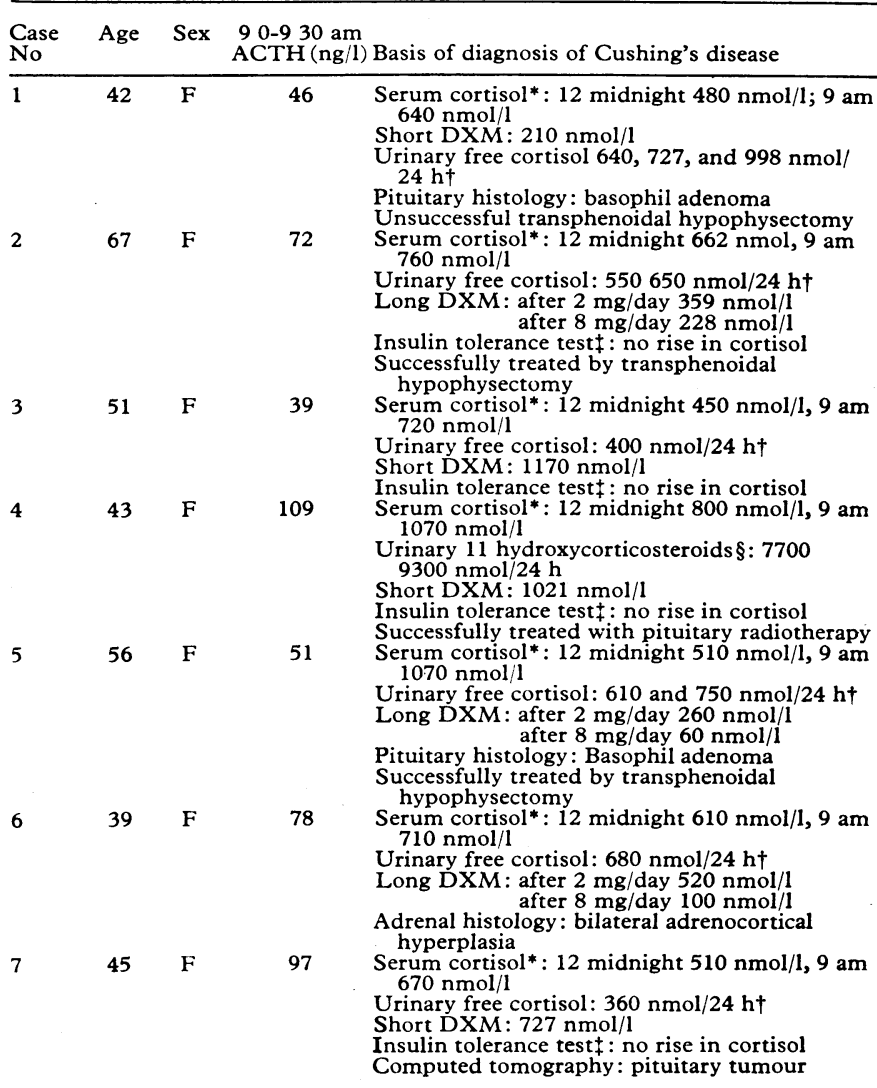

Short DXM $=9$ am measurement of cortisol after $1 \mathrm{mg}$ dexamethasone at $10 \mathrm{pm}$ previous night.

Long DXM $=0.5 \mathrm{mg}$ dexamethasone eight-hourly for 48 hours followed by $2 \mathrm{mg}$ dexamethasone eight-hourly for $\mathbf{4 8}$ hours.

(140 nmol/; 9 am $150-700 \mathrm{nmol} / 1$

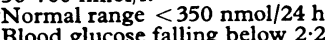

Normal range $220-1050 \mathrm{nmol} / 24 \mathrm{~h}$. 
plasma stored at $-20^{\circ} \mathrm{C}$ until assayed. ACTH was measured by radioimmunoassay using the method of Rees et al, 4 but with modifications that have been previously described. ${ }^{5}$ The sensitivity of the assay was $7 \mathrm{ng} / 1$ (extracting $5 \mathrm{ml}$ of plasma); the intra-assay coefficient of variation was $8 \%$; and the interassay coefficient of variation was $14 \cdot 8 \%$.

\section{Results}

Figure 1 shows the ACTH concentrations in the 58 normal controls and seven patients. The values ranged from 9 to $77 \mathrm{ng} / \mathrm{l}$ for the 58 controls, irrespective of the time of venepuncture; from 9 to 24 $\mathrm{ng} / \mathrm{l}$ for the 21 controls whose venepuncture was between 90 am and $930 \mathrm{am}$; and 39-109 ng/l for patients with Cushing's disease. Figure 2 shows ACTH concentrations of the 58 controls plotted against time of sample.

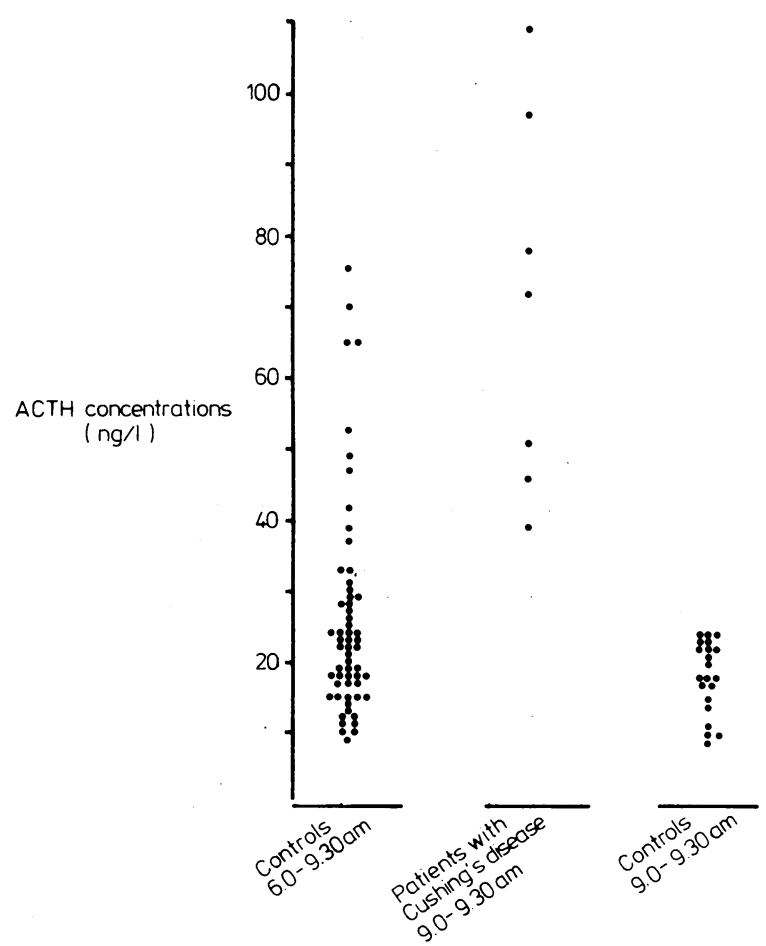

FIG 1-Plasma ACTH concentrations in normal controls (measured between 60 am and $930 \mathrm{am} ; 21$ between $90 \mathrm{am}$ and $930 \mathrm{am}$ ) and patients with Cushing's disease (measured from 90 am to $930 \mathrm{am})$.

\section{Discussion}

Morning plasma concentrations of ACTH in patients with pituitary-dependent Cushing's syndrome are commonly believed to overlap with the normal range. ${ }^{6-9}$ The normal range, however, is usually described as being derived from blood samples taken between $8 \mathrm{am}$ and $9 \mathrm{am}^{9}$ or between $8 \mathrm{am}$ and $10 \mathrm{am}^{2}{ }^{2}$ Both our normal range and our ACTH concentrations in patients with Cushing's disease compare well with those quoted by the above authors. As can be seen from fig 1 the samples from patients with Cushing's disease do indeed overlap this normal range if the timing of the samples are not taken into account. ACTH secretion in normal subjects is not constant, particularly between 8 am and $10 \mathrm{am}^{810}$ and we have confirmed that concentrations fall after the morning peak, as shown in fig 2 . The range between 90 am and 930 am is much narrower and is from 9 to $24 \mathrm{ng} / \mathrm{l}$. Although we were able to study only a limited number of patients with Cushing's disease, the range of ACTH concentrations found in this condition did not overlap the true 9 0-9 30 am normal range. In addition, we found no published report of a case of Cushing's disease with morning concentrations less than $24 \mathrm{ng} / \mathrm{l}$.

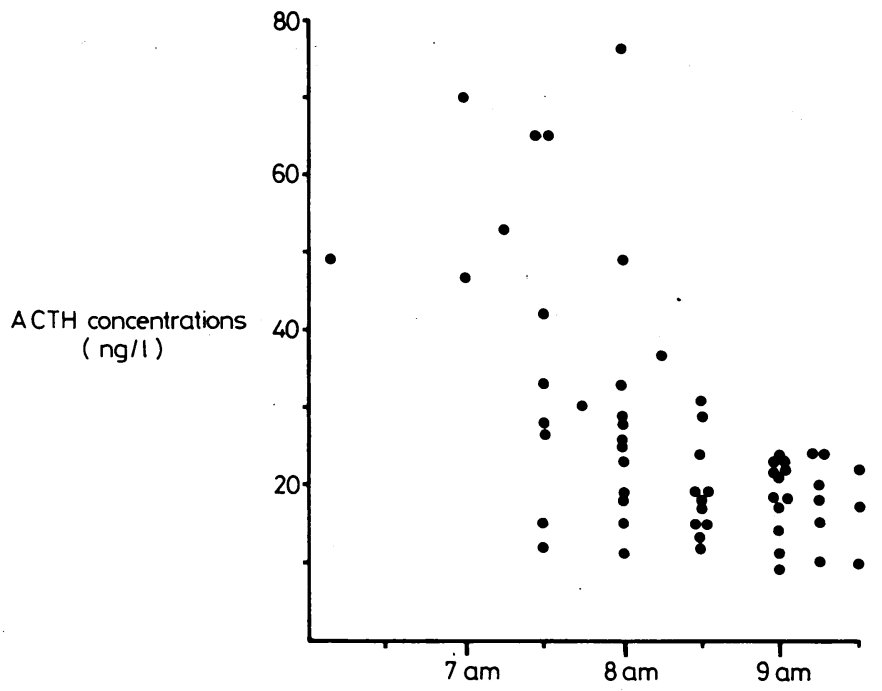

FIG 2-Morning plasma ACTH concentrations of 58 controls plotted against time of sample.

This finding supports the suggestion that ACTH secretion in Cushing's disease is fairly constant throughout the 24 hours. It is inevitable, therefore, that ACTH concentrations in some patients will fall into the range of the normal morning ACTH surge and that slightly later in the day, when normal concentrations have fallen, concentrations in these patients will be seen to be raised.

Although we have not measured any of the other proopiocortin peptides in this study, our finding may also apply to them, since they are secreted in parallel to ACTH. Thus the normal values of $\beta$-lipotrophin, $\beta$-endorphin, or pro-opiocortin itself should also be defined more closely, with particular respect to the timing of the blood samples.

We are grateful to Professor $\mathrm{L} \mathrm{H}$ Rees for donating the ACTH antiserum, to Dr P Lowry for donating synthetic ACTH, and to Blood Products Laboratories for donating human serum albumin used in the assay. We thank Dr W van't Hoff, Professor R Hoffenberg, and Dr D A Heath for allowing us to study their patients. Dr P M Horrocks was supported by the West Midland Regional Health Authority, as a Sheldon Clinical Research Fellow, for a part of the study.

\section{References}

1 Yalow RS, Glick SM, Roth J, Berson SA. The radioimmunoassay of human plasma ACTH. f Clin Endocrinol Metab 1964;24:1219-25.

2 Landon J, Greenwood FC. Homologous radioimmunoassay for plasma levels of corticotrophin in man. Lancet 1968;i :273-6.

3 Orth DN, Island DP, Nicholson WE, Abe K, Woodham JP. In: Hayes RL, Goswitz FA, Murphy BEP, eds. Radioisotopes in medicine: in vitro studies. Oak Ridge, Tennessee: US Atomic Energy Commission, Division of Technical Information, 1968:251-72.

4 Rees LH, Cook DM, Kendall JW, et al. A radioimmunoassay for rat plasma ACTH. Endocrinology $1971 ; 89: 254-61$.

5 Horrocks PM, London DR. A comparison of three glucocorticoid suppressive regimes in congenital adrenal hyperplasia. Clin Endocrinol $(O x f)$ (in press).

6 Donald RA. ACTH and related peptides. Clin Endocrinol (Oxf) 1980; 12:491-524.

7 Besser GM, Landon J. Plasma levels of immunoreactive corticotrophin in patients with Cushing's syndrome. Br Med f 1968;iv:662-4.

8 Rees LH. Human adrenocorticotrophin and lipotrophin in health and disease In: Martini L, Besser GM, eds. Clinical neuroendocrinology. New York: Academic Press, 1977:401-41.

${ }^{9}$ Krieger DT, Liotta AS, Suda T, Goodgold A, Condon E. Human plasma immunoreactive litotrophin and adrenocroticotrophin in normal subjects and in patients with pituitary adrenal disease. 7 Clin Endocrinol Metab 1979;48:566-71.

10 Krieger DT, Allen W, Rizzo F, Krieger H. Characterisation of the normal temporal pattern of plasma corticosteroid levels. $\mathcal{f}$ Clin Endocrinol Metab $1971 ; 32: 266-84$

(Accepted 24 August 1982) 